\title{
Identifying Gaps between the Legislative Tools of Soil Protection in the EU Member States for a Common European Soil Protection Legislation
}

\author{
Petra Stankovics ${ }^{1}$, Gergely Tóth ${ }^{2,3, *(\mathbb{B})}$ and Zoltán Tóth ${ }^{1}$ \\ 1 Department of Crop Production and Land Use, University of Pannonia Georgikon Faculty, \\ 8360 Keszthely, Hungary; stankovics.petra@gmail.com (P.S.); tothz@georgikon.hu (Z.T.) \\ 2 Department of Soil Science and Environmental Informatics, University of Pannonia, \\ 8360 Keszthely, Hungary \\ 3 Institute for Soil Sciences and Agricultural Chemistry, Centre for Agricultural Research, Hungarian \\ Academy of Sciences, 1022 Budapest, Hungary \\ * Correspondence: toth.gergely@georgikon.hu
}

Received: 12 April 2018; Accepted: 10 August 2018; Published: 14 August 2018

\begin{abstract}
To ensure an adequate level of protection in the European Union (EU), the European Commission (EC) adopted the Soil Thematic Strategy in 2006, including a proposal for a Soil Framework Directive (the Directive). However, a minority of Member States (United Kingdom, Germany, France, Austria, and The Netherlands) could not agree on the text of the proposed Directive. Consequently, the EC decided to withdraw the proposal in 2014. In the more than 10 years that have passed since the initial proposal, a great number of new evidences on soil degradation and its negative consequences, have proved the necessity of a common European soil protection Directive. This study is aimed at specifying the possible obstacles, differences, and gaps in legislature and administration in the countries that formed the blocking minority, which resulted in the refusal of the Directive. The individual legislations of the opposing countries on the matter, were summarized and compared with the goals set by the Directive, in three highlighted aspects: (1) soil-dependent threats, (2) contamination, and (3) sealing. We designed a simple schematic evaluation system to show the basic levels of differences and similarities. We found that the legislative regulations concerning soil-dependent degradation and contamination issues in the above countries were generally well defined, complementary, and thorough. A common European legislation can be based on harmonised approaches between them, focusing on technical implementations. In the aspect of sealing we found recommendations, principles, and good practices rather than binding regulations in the scrutinised countries. Soil sealing is an issue where the proposed Directive's measures, could have exceeded those of the Member States.
\end{abstract}

Keywords: soil degradation; soil functions; soil framework directive; soil policy; soil threats; contamination; sealing

\section{Introduction}

Soils are under ever-increasing pressure, since global population growth brings an increasing demand for food [1]. Although soils are one of the most important natural resources on the planet, their ecological importance is often greatly underestimated. On account of urbanisation, road construction, and pollution, three square kilometres of soil are destroyed every day in the European Union (EU) [2]. If nothing is done to stop soil erosion, by the year 2050 the world will lose fertile soil covering 1.5 million square kilometres, which is the land area of Germany, France, and Spain combined [3]. The 7th Environment Action Programme (EAP), which is guiding European environmental policy until 
2020, recognizes that soil protection is a serious challenge. The EAP wants the EU to be a place where natural resources are managed sustainably, and biodiversity is protected and valued [4]. It requires the EU and its Member States to increase efforts to reduce soil threats and to remediate contaminated sites. The EAP, prescribes the integration of land use aspects into coordinated decision-making, involving all relevant levels of government. It also states that soil quality issues could be addressed using a targeted and proportionate risk-based approach, within a binding legal framework [5].

Despite the instructions of the EAP, the regulations on soils are not sufficient in all cases to ensure an adequate level of protection in the EU. Though protection provisions indirectly contribute to the protection of soils in the Community acquis in areas such as agriculture, water, and environment, there is no specific EU legislation on soil protection [6], and only a few Member States have specific legislation on it [7]. To better understand the situation, The Environmental Assessment of Soil for monitoring (ENVASSO) Project was launched [8] and the EC adopted the Soil Thematic Strategy in 2006 including a proposal for a Soil Framework Directive (the Directive), with the objective to protect soils across the EU. The EC had proposed the Directive with the objective of establishing a common strategy, for the protection and sustainable use of soil. This was based on the principles of integration of soil concerns into other policies, preservation of soil functions within the context of sustainable use, and prevention of threats to soil and mitigation of their effects; together with the restoration of degraded soils, to a level of functionality consistent with the current and approved future use. It included a requirement for Member States to identify soil protection priority areas within five years after the enforcement of the Directive, and take appropriate measures to protect against erosion, biodiversity loss, and other threats [9]. Member States would have been required to take specific measures to address soil threats, but the Directive left ample freedom on how to implement the legislation concerning these requirements.

However, a minority of Member States (The United Kingdom, Germany, France, Austria, and The Netherlands) could not accept the text of the proposed Directive. Subsidiarity considerations, excessive cost, and administrative burden [10] were among the reasons of refusal to accept the European law on soil protection. Consequently, the EC decided to withdraw the proposal in 2014. Thus, an opportunity was missed for the protection of soil based on a common legislative document within the EU, the targets of which are still vitally required.

In the more than ten years that have passed, since the initial proposal of a common European Soil Protection Directive, a great number of new evidences on soil degradation and its negative consequences have proved its necessity [11,12]. The areas of subsidiarity and administration have manifold legal implications. This study aims at specifying the possible obstacles, differences, and gaps between the goals set by the Directive and the legislature and administration in the countries that formed the blocking minority, resulting in the refusal of the Directive. The current study focuses on the legislative and administrative aspects present in the five countries and does not aim to make a comprehensive assessment for all EU Member States, nor an assessment of any political or economic motivation that may be present when regulating the protection of soil resources.

\section{Materials and Methods}

The materials used in the research part of the study include the Directive, and English citations of legal documents of the blocking five Member States at national, regional and local levels. The sources were the official governmental websites, the official website containing EU laws (EUR-Lex), online international law information services (e.g., Wolters Kluwer), and national legal experts' contributions (e.g., websites, articles, comments). The different types of legal acts (see also at Vrebos et al. [13]), such as: Regulations - binding legislative acts, which must be applied; directives_legislative acts that sets out goals; decisions_-binding on those to whom they are addressed and are directly applicable; recommendations; communications; and opinions were assessed according to the level of legal obligation they represent. 
The assessment is based on the categories of the Directive. We condensed the soil protection objectives of the Directive into three coherent groups: (1) soil-dependent threats-embracing erosion, organic matter decline, salinization, compaction, and landslides; (2) contamination; and (3) sealing. Grouping was based on the role of inherent soil properties in the degradation process. The threats classified in the first group were those where soil characteristics are important factors in the degradation process. Contamination (2) and sealing (3), typically do not depend on the properties of the affected soil and differ in their characteristics (i.e., driver, impact, etc.) among themselves too, therefore are considered separately. The study aimed at giving a clear view of these three aspects, within each examined country.

Regarding the national policies of the blocking five countries, the following: (i) responsible legislative and administrative bodies and (ii) legislative and administrative tools in effect, were assessed. Legislative bodies are those creating regulations and administrative bodies are responsible for the observation and implementation of these regulations. The different levels of implementation (national, regional, local) are clarified in the respective sections.

In the compilation and grouping of the researched material, we found that we can assess four categories concerning the gaps (i.e., differences and levels of similarity) existing between law making and practices of the blocking countries, and the proposals of the Directive. The four categories we determined were: $(--)$ no legislation available; $(-)$ legislation exists, but with different conceptual approach and different implementation; $(+)$ legislation exists with a similar conceptual approach but different implementation; and (++) legislation exists with a similar conceptual approach and similar implementation. It was also important for us to show the differences and similarities within the blocking five Member States (this is why we compared them in one table), to get a clear overview of the gaps this paper was aimed at identifying.

To place our research findings in the context of the current scientific discussion involving the necessity of common EU soil protection regulation, we briefly reviewed the main focuses of the ongoing dispute in the Discussion section. The research strategy for this assessment comprised of searches on legal, political, economic, and societal considerations of soil protection in the EU.

\section{Results}

\subsection{Provisions of the Proposed European Soil Framework Directive}

\subsubsection{Provisions for Soil-Dependent Threats}

Erosion, organic matter decline, salinization, compaction, and landslides were addressed within the legal framework. Within five years from transposition date, Member States should have identified the risk areas in their national territory, where there was evidence or suspicion that one or more soil degradation processes had occurred or would have been likely to do so in the near future. Member States may have based the identification of risk areas on empirical evidence or on modelling. The risk areas were to have been reviewed every ten years [14]. Under each risk area, Member States were to draw up a programme of measures including risk reduction targets, the appropriate measures for reaching those targets, a timetable for implementation, and an estimate of the funding allocation. Member States were encouraged to use their own existing monitoring schemes and improve them if necessary. Programmes could have built on measures already implemented at national and EU level, such as cross-compliance and rural development under the Common Agricultural Policy (CAP), codes of good agricultural practice and action programmes under the Nitrates Directive, future measures under the river basin management plans of the Water Framework Directive, national forest programmes and sustainable forestry practices, and forest fire prevention activities. These approaches to combat threats to soil could have been combined as well, benefiting in particular those Member States which had already been addressing soil loss [15]. 


\subsubsection{Provisions for Contamination}

Local contamination would have been tackled at the regional or national level [16]. According to the Directive, Member States would have been required to identify contaminated sites in their national territory and establish a National Remediation Strategy, on the basis of a common definition and a common list of potentially polluting activities [17]. Each Member State was asked to designate a competent authority responsible for the identification of contaminated sites, and their status was planned to have been reviewed every five years [18]. Where containment or natural recovery were applied, the evolution of the risk to human health or the environment should have been monitored.

In the Directive, it became a state priority to create a sound and transparent system to ensure that contaminated sites would be remediated, and all entailed risks be reduced. Member States were also required to set up appropriate mechanisms to fund the remediation of the contaminated sites. To exercise control through terms of sale, it initiated the obligation for a seller or a prospective buyer to provide to the administration and to the other party in the transaction, a soil status report for sites where a potentially contaminating activity had taken place [19]. In cases when, the polluter pays principle cannot be exercised, namely the person responsible for the pollution cannot be identified or cannot be held liable under Community or national legislation or may not be made to bear the costs of remediation, the Member States have to refer to their own appropriate mechanisms for the funding of the remediation.

\subsubsection{Provisions for Sealing}

In connection with sealing the Directive, it was clarified that Member States should take appropriate measures to limit it where it is carried out for the purposes of preserving the soil functions [20]. To achieve a more rational use of soil, Member States would have been required to rehabilitate brownfield sites, and to mitigate the effects of sealing using construction techniques and products that preserve as many soil functions as possible.

\subsection{Soil Policies in the Blocking five Member States}

\subsubsection{United Kingdom}

Soil protection administration has a complex structure in the UK and several pieces of legislation include provisions for soil protection, however, no single soil protection act exists. DEFRA (the Department for Environment, Food and Rural Affairs) has responsibility for overall soil policy in England, and it funds a wide range of research in partnership with other organisations. For example, the Environment Agency (EA) for environmental protection in England and Wales, and the new Department for Communities and Local Government (DCLG) for planning policy. Scotland, Wales, and Northern Ireland have separate, devolved bodies that deal with soil [21]. In Scotland, the Scottish Soil Framework [22] has been in effect since 2009, in Wales, the Environment Strategy for Wales [23] has covered the issue since 2006. England has existing programmes, such as CAP cross compliance, Environmental Stewardship, the England Catchment Sensitive Farming Delivery Initiative, and the new Code of Good Agricultural Practice. In accordance with current legislation, farmers need to comply with the cross-compliance soil management standards. These requirements are: Good Agricultural and Environmental Conditions (GAECs) and Scheduled Monuments Statutory Management Requirements (SMRs) [24]. These standards require landowners to identify and record any existing and potential problems with their soil and assess their risks of degradation, based on soil type, landform, rainfall, and present land use information. Furthermore, they need to carry out measures to prevent or reduce the problems and risks they have identified [25]. In the matter of legal penalties, landowners may have their scheme payment(s) reduced if they don't meet all the GAEC and SMR cross compliance rules, which apply to their holding.

Concerning the rehabilitation of contaminated land, there are two main statutes, the Environmental Protection Act 1990 (EPA) and the Environmental Damage Regulations 2015 (EDR). The EPA aims to ensure that contaminated land is identified and remediated, where it poses unacceptable risk levels. 
The EDR relates to the prevention and remediation of environmental damage in the most serious cases. In 2012, DEFRA published a Statutory Guidance for England on dealing with contaminated land and radioactive contaminated land. In case of contamination, the principal enforcement authority is the relevant local authority. They must inspect their risk areas to identify any contaminated land and record them in public registers. Under the EDR, operators-land users-must take all practicable steps to prevent environmental damage if there is an imminent threat of damage. If environmental damage has already occurred, it is the operator's responsibility to prevent further damage. If the regulator considers that environmental damage has occurred, it can serve a remediation notice on the responsible operator setting out measures that must be taken. In cases of new developments on a site with contaminated land, planning authorities can impose conditions in the planning permission requiring remediation to be carried out before the development starts. Failure to comply with a remediation notice, without a reasonable excuse, is a criminal offence punishable by a fine. The regulator can carry out the remediation itself and recover the costs from the relevant parties. The liability for the remediation of contaminated land rests, initially, with those who caused or knowingly permitted the contamination. If neither of the above can be found, liability passes to the owners of the land, regardless of whether they were responsible for the contamination or were aware of its existence. Liability does not change when land is transferred. Unless one of the various exclusions applies [26], previous owners or occupiers who caused contamination, remain liable after the sale of the land. However, an owner who is not a polluter will no longer be liable when they cease ownership or occupation of the site [27].

According to the governmental soil strategy, since some degree of soil sealing is an unavoidable consequence of development, the environmental, economic, and social costs and benefits of the development and use of land should be balanced and the negative impacts of soil sealing mitigated, particularly in relation to urban drainage and maintaining green infrastructure [28]. Monitoring of soil sealing is consistent, even afforded by using airborne imagery [29].

\subsubsection{Germany}

Soil protection is carried out at the federal and local levels in Germany. The UBA (Umweltbundesamt) as Germany's main environmental protection agency and the Federal Ministry of Environment, are the main legal authorities which compile, assess, and provide information on soil status, soil conservation, and optimization of measures. The federal government lays down the legal frameworks, which are implemented by the regional states. One of the main regulations is the Federal Soil Protection Act (BBodSchG, 1998). It aims at sustainability by securing or restoring soil functions by administering safety measures and provisions against harmful effects on soils, with a focus on the rehabilitation of contaminated sites [30]. Farmers are required to comply with specified standards, called good agricultural practices [31]. These are based on the stipulation that any deleterious impact on natural soil functions is to be avoided insofar as possible [32]. The other leading code of practice is the Federal Soil Protection and Contaminated Sites Ordinance (BBodSchV, 1999). It lays down precautionary soil values for particularly important contaminants, contains hazard prevention and measurement values, together with soil investigation and assessment procedures [33]. The Federal Nature Conservation Act (BNatSchG) states that interventions in nature and landscape are to be avoided or offset. Article 15 (7) BNatSchG states that a statutory ordinance can regulate the details of offsetting interventions. In effect, this could introduce standards relating to interventions with soil and corresponding offsetting measures.

In Germany, contaminated-site remediation is based on a graduated concept. Suspected site contamination is verified by the existence and concentration of hazardous substances, and their impact on receptors and other natural resources. Official identification of site contamination, normally results from a definitive hazard assessment and forms the basis for protective and remediation measures [34]. If investigation or remediation actions on a site are required, liability is not limited to the person (or company) who caused the contamination. Those who own or possess the site or have owned it in the past, can be held liable by the authorities as well, even if the polluter is still present and solvent [35]. 
There is no regulation like a liability relief for small businesses or even private persons. There is no funding of clean-up or investigation, except for public authorities [36].

There are a number of laws that serve to reduce the extent of soil sealing (Federal Building Code §1a, Federal Spatial Planning Act §2 or Federal Soil Protection Act §1, §5, and the Federal Nature Conservation Act \$1) [37]. At the regional level, building law and regional planning law also contain provisions relevant to soil. The Federal Building Code, states that land shall be used sparingly and with due consideration. This principle must be considered in urban planning in particular. Regional planning law contains regulations regarding overall area planning, and thus the use of land and soil. The relevant provisions at federal level are contained in the Federal Regional Planning Act (Raumordnungsgesetz). The Länder have corresponding Land legislation [38]. The Federal Government in 2017, adopted a Sustainable Development Strategy to clarify how Germany can achieve "land degradation neutrality" domestically [39]. In it, representatives of research, policy, and civil society agreed that soil sealing and land take need close monitoring, which relates to an existing policy goal (the "30-ha goal") [40] and could be extended towards other targets and indicators [41].

\subsubsection{France}

In France, the national information system on soils falls under the leadership of "GIS Sol". The Members of the Organisation are the Ministry of Agriculture and of Environment, the Environment and Energy Agency (ADEME), the National Institute for Agricultural Research (INRA), and the Research Institute for Development (IRD). The objective of the GIS Sol is to answer the needs of soil information at regional and national levels, to public authorities and society through the coordination and realization of soil survey and soil monitoring in France, to manage an information system on the spatial pattern, properties, and quality evolution of the French soils [42]. At a local level, the local governments and Regional Directorates of Environment, Planning and Housing have general administrative enforcement powers, as well as derogatory emergency police powers in case of serious risks, including pollution like soil contamination from a factory [43]. In every one of the 101 directorates, a prefect representing the state is responsible for granting environmental permits and controlling compliance with regulations. French courts also play a critical role in soil protection. Administrative courts have jurisdiction over state and public authorities' decisions regarding soil protection. Civil courts hear civil liability cases, and criminal courts have the power to try and prosecute environmental criminal offences. The regulation of soil protection is substantially influenced by EU Law, the main statutes are the Environmental Charter of 2005, of constitutional rank; and the Environment Code, in which most of the relevant laws and decrees have been codified $[44,45]$.

Regarding land contamination, environmental protection and waste regulations (ICPE [46] and Articles L. 541-1 of the Environment Code, and since 2014, the Chapter "Contaminated sites and land" of the Environment Code [47]) are in effect. ICPE regulation involves a proactive regulatory watch on soil problems, and there are also administrative and criminal sanctions provided by ICPE. Waste regulations can apply to non-compliance with clean-up provisions. Where known soil contamination justifies investigation and contamination management measures, in particular when the use of the land changes, the state classifies the land within a "land information sector" and publishes relevant information about the land [48]. In the event of soil contamination, the enforcing authority can perform of its own accord the necessary works, at the expense of the responsible party. If the site cannot be remediated because the responsible party disappeared or is insolvent, the state can entrust the ADEME with the remediation [49]. As far as liability goes, parties for the clean-up of contaminated land are, by order of priority, the last operator of the facility causing the contamination and secondarily, if no party is primarily responsible, the owner of the contaminated land can be held liable for negligence or contribution to the contamination [50]. An ICPE operator's liability is limited by the causal link between the permitted activities and the pollution. Concerning site remediation, barring migrating pollution, liability is limited by the future use of the site [51]. 
The National Strategy for Sustainable Development includes a new sustainability objective that defines the aim of land take reduction. The strategy for sustainable development puts emphasis on the reduction of sealing. Since 2010, the law Grenelle Environment has been enforced. Its most relevant action line for the reduction of land take and soil sealing, is the improvement of energy standards of buildings and harmonization of spatial planning, which stipulates energy efficient urban structures by supporting inner urban development and avoiding further soil consumption, mainly by brownfield redevelopment and urban renewal. France disposes of a network of more than 20 public land development agencies (EPF), who operate at the regional, but also at the local level to develop land for social housing [52].

\subsubsection{Austria}

Soil Protection has been declared a national target with the Federal Constitutional Law on Comprehensive Environmental Protection, but there is no comprehensive federal law on soil protection in Austria [53]. According to the Constitution, governmental responsibilities for environmental issues are allocated to the federal state, the nine provinces, and the local authorities. The Ministry for Agriculture, Forestry, Environment and Water Management is the competent environmental authority. At the provincial level, the governments of the provinces and the district authorities are responsible for administering environmental law. The Federal Environment Agency deals with monitoring and documenting the Austrian environmental situation, and the regions are fully responsible for the central instruments of land management as spatial management laws, nature conservation laws, and laws concerning housing development aid. There is also a third, local, municipal level present in Austria. Land planning and development of land resources, and land-management by surface-dedication and development, lies in the hands of the more than 2000 municipalities. Specifically, soil protection lies in a mosaic of regulations. There are three principal systems of soil survey in Austria: On forested land the Forest Soil Survey, on agricultural land the Soil Taxation Survey, and the Soil Management Survey. In addition, there is an Environmental Soil Survey, a Soil Monitoring System, and a Soil Information System (BORIS) [54]. The assessment of soil quality is based on provincial soil protection regulations. Soil Protection Acts have been enacted in 5 provinces (Burgenland, Lower Austria, Upper Austria, Styria, and Salzburg), but with differing measurements of soil qualities and soil sensitivity classes [55]. Soil protection on both the federal and local level, is aided by the traditional cadastre updated into a modern monitoring system by GIS. Today, legal security of tenure and land-ownership is given by the system of the land register, covering the whole territory and involving the development and use of land-use indicators and related monitoring systems. Detailed land use descriptions are partially included in the cadastre, and in GIS applications. GIS is used for integrated planning and management of land resources. It integrates the spatially referenced information of land use and soil, and systematically captures, stores, and manages data. GIS is used both by federal and Laender authorities to support planning and policy implementation [56].

Concerning soil contamination there is no integrated regulatory regime, but applicable provisions are spread over a considerable number of laws and regulations (for example, the Trade Act, the Federal Waste Management Act, the Federal Environmental Liability Act, the Forest Act, and the Water Act). The Clean-up of Contaminated Sites Act and the Directive on Funding Clean-Up of Contaminated Sites 2008, stipulate provisions for the remediation of contaminated sites. The latter also sets out rules with regards to the public funding of remediation measures [57]. The main principle regarding the liability for contaminated land is the "polluter pays" principle. Under certain conditions, the property owner may also be held liable for soil contamination. If a site is identified as contaminated, the regulatory authority must first try to trace the polluter. Either the 'polluter or, if not traceable, the property owner may be held secondarily liable to take proper preventive or remediation measures or to bear the costs, or both. The same applies to the legal successor of the property owner, provided that the successor knew or should have known of the endangering activity. In terms of damage affecting the land, the Federal Environmental Liability Act requires that the land concerned, be decontaminated 
until there is no longer any serious risk of negative impact on human health. The costs must be met by the operator (the potential polluter). In case the operator is incapable, the competent authority will take preventive or restorative measures itself, and recover the costs incurred later. Where several instances of environmental damage have occurred, the competent authority may determine the order of priority according to which they must be remedied. Polluter liability is a strict liability. However, the blameworthiness of environmentally damaging conduct is decisive as to the eligibility for funding of remediation and safeguard measurements. Financial assistance may be available for remediation and safeguard measures, under the Directive on Funding Clean-Up of Contaminated Sites 2008. No financial assistance of clean-up measures is granted if the applicant caused the contamination in a premeditated or grossly negligent manner [58].

In 2002, the annual rate for soil sealing amounted to 9 hectares per day. The Austrian Strategy for Sustainable Development declared the target of a sealing rate below 1 hectare per day. The overall objective of this policy target was to stop the increasing fragmentation of landscapes, and to conserve soil functions as far as possible. Since then soil sealing is being monitored and published every two years in the Report on Monitoring Sustainable Development. The Strategy recommends enhancing inner urban development, to increase the efficiency of land use and the quality of living in small cities; to allow new land developments only along top public transport lines; and to re-develop brownfield sites and protect landscapes and recreational areas. All Austrian provinces have recently adopted their spatial planning regulations, efficient land use is a priority and new instruments are available to allow reduction of land take. Spatial planning follows a strong federal structure. At the national level, Concepts for Spatial Development (ÖROK) are published on a regular ten-year basis. The nine Austrian provinces dispose of their own spatial planning laws, which are regularly adopted and reflect the recommendations of the actual ÖROK document. Final planning decisions are made at the municipality level, under the supervision of the provincial governments [59].

\subsubsection{Netherlands}

The Netherlands are divided into 12 provinces. The provinces form an administrative layer between the central government and the municipalities. In close cooperation with the central government, the municipalities, and the district water boards, the provinces usually perform duties in soil protection. Recently, the central government has transferred an increasing number of duties to the municipalities. Based on the Soil Protection Act (Wbb) and the Environmental Protection Act (Wm) some municipalities have more duties and powers than other municipalities with regard to soil policy and management. In general, these 'competent authority' municipalities are the large municipalities, such as Amsterdam, Rotterdam, and Utrecht. This means, for example, that duties normally performed by a province are instead implemented by the competent authority municipality [60]. The Ministry of Housing, Spatial Planning and Environment oversees making and enforcing soil protection policy and bears responsibility for the sustainable use of the soil. The Netherlands Soil Protection Guideline (NRB) for Industrial Activities (which has been confirmed at administrative level by the Ministry of Housing, Spatial Planning and the Environment; the Directorate General for the Environment (VROM/DGM); the Union of Water Boards; the Association of Provinces; and the Association of Netherlands Municipalities within the Soil Steering Party (Stubo)) has a powerful steering function, as it has the status of a harmonising tool, for assessing the need and reasonableness of soil protection measures and facilities. However, the NRB is not legally binding because it has no formal legal status. The NRB only becomes legally binding once it has been converted into conditions, in permits or general administrative orders [61]. An important body in soil protection is SenterNovem/Soil+. It is a task group in the SenterNovem agency, an agency of the Ministry of Economic Affairs. It pursues government policy in various policy areas, such as innovation, the environment, and sustainability. However, it is an assignment of the Ministry of VROM and acts as a link between policy formation by the central government, and the actual implementation of these policies by the provinces, municipalities (competent authorities), and district water boards [62]. 
Two of the most important laws that serve as the foundation for Dutch soil policy, are the Soil Protection Act and the Environmental Protection Act [63]. The Soil Protection Act contains general rules to prevent soil contamination. The Environmental Protection Act (Wm) is the most important environmental law, which establishes that permits must be obtained before certain activities may be performed. Under soil policy, this law means that permits must state the extent to which companies must make provisions to protect the environment and the land. A responsibility to return the soil to its original state may also be in force. In most cases, the permits are issued by the municipalities or the provinces. Important legislation in the current soil policy, for dealing with soil pollution and guaranteeing conscious and sustainable soil management includes the Soil Quality Decree [64]. The Soil Remediation Circular 2013, serves as a supplement to the Soil Protection Act. This circular is adapted to the new soil management policy as set out in the Soil Quality Decree, and applies to dry land. It contains guidelines for the use of remediation criteria and the determination of remediation goals in the case of soil pollution. Municipalities and provinces can use the remediation criteria to determine the severity of the pollution, and whether a site needs urgent remediation. The Cost Calculation Model (AOA), provides a standard to assist in an objective consideration of the costs for an area-oriented approach or the aftercare of soil remediation [65]. There are also some networks used as instruments regarding site investigation, soil sampling strategies, soil treatment and reuse, remediation technologies, chemical analyses, etc. [66].

National Spatial Planning Programmes are published approximately on a ten-year basis by the Ministry for Housing, Spatial Planning and the Environment (Rijksoverheid). The most recent development is the Nota Ruimte (NR) programme, which was enacted by the Dutch parliament in 2006. The programme gives guidance for the national spatial development until 2020 and provides a vision for the spatial development until 2030. The overall objective of the programme is decentralisation: the realisation of a polycentric society and a withdrawal of central structures. The issue of land take reduction is now under the responsibilities of the provinces. The objective of reducing sealing and landscape fragmentation is reflected in several spatial planning documents, like the Order on Council Spatial Planning (AMvB Ruimte), which reconfirms national aims to reduce urban sprawl and to establish a national ecological network; the Action Programme against landscape cluttering (Beautiful Netherlands), which aims to reduce development of new commercial zones by redeveloping the old commercial zones; or the long-range programme for habitat defragmentation (Meerjarenprogramma Ontsnippering). Brownfield redevelopment funding schemes have also been moved to the local authorities [59]. In 2008, the new Dutch Spatial Planning Act came into effect. It reflects that though spatial planning is rather flexible in The Netherlands, it has recently become overly detailed and easily outdated [67].

\section{Discussion}

At present, neither the preservation of soil functions nor the management of soil threats are comprehensively regulated by the EU legislator, and soil protection seems to be merely the by-product of different provisions which are mainly preventive, qualitative, and non-strictly binding [68]. The Directive would not necessarily have exceeded these in mandatory authority but could have provided a legal background for the enhancement of these issues and served as legal reference beyond national governments.

Results show (Table 1) that in the first two categories of legal acts ((1) soil-dependent threats, (2) contamination issues) the five blocking countries do have equally, or in cases even more binding measures. The legislative regulations concerning soil-dependent threats and contamination issues in the above countries were generally well defined, complementary and thorough, but because of their fragmented character may not serve sustainable soil use as sufficiently as they could. This is well demonstrated by the fact, that in some states, for example Austria, soil protection guidelines were not coherent among different administrative regions there being no concerning national law. While some federal states have very extensive soil protection legislation (e.g., Salzburg) or non-binding 
soil-focused instruments, such as the Soil Protection Concept Vorarlberg, there is no soil protection legislation in some other federal states [69]. In the aspect of sealing (3) the gaps are more significant. We found recommendations, principles, and good practices rather than binding regulations in this area. Sealing is not a separate issue, but is mainly incorporated into urban spatial planning, e.g., a planning system (UK), the National Strategy for Sustainable Development (France), Building Code (Germany), and National Spatial Planning Law (The Netherlands), as shown in Table 1. The current perception on sealing is that it is an unavoidable consequence of development [70]. Ecological sustainability considerations are often limited to the assessment of environmental, economic, and social costs and benefits of the specific land take, without considering the no-land-take alternatives. There are good initiatives too, which increasingly recognise the importance of mitigating the impacts of soil sealing, e.g., in relation to urban drainage and maintaining green infrastructure. However, as extensive literature suggests, these incentives are frequently pushed into the background by funding mechanisms and power configurations, which influence the implementation of spatial strategies integrated in strategic plans [71-73].

The Member States of the EU did not reach a political agreement about an overarching legislative control system over soil protection. The UK, Germany, France, Austria, and The Netherlands have argued that the new Directive would not respect the principle of subsidiarity and would interfere with domestic soil policy. Their objection was specifically about Member States' rights in the EU. The British and German governments claimed that unlike air and water, soil is not a cross-border issue and therefore the EU had no right to regulate it [74]. They were concerned about the extra costs of soil protection in other, possibly more problematic Member States and additional policy obligations, as well as a possible restriction on housing developments, and criticised the proposal on the grounds that it would lead to disproportionate cost with a negligible environmental benefit. As public concern over sovereignty and bureaucracy within the EU increased, these governments saw the proposed EU legislation as unnecessary meddling in an area best dealt with at the local level. Farmers lobbied intensely against the legislation too. It was also argued that soil is already protected under such EU legislation as the CAP [75].

On the other hand, the issue of soil degradation is widely accepted as having multiple cross border consequences. Soil degradation is also continuous in Europe, and the achievements in endeavours for a more sustainable use of soil diverges enormously between Member States [76]. Consequently, existing policies are apparently insufficient for preserving soil functions. There seems to be a need to ensure that all Member States are addressing all threats to which soils are confronted in their national territory, and do not do so in a partial way. On account of the national approaches, no common thresholds, monitoring targets, and priorities are in effect. There are strategic vision documents but they are mostly non-binding. Soil protection is regarded rather as a beneficial side effect, and not as a primary objective at present. In fractured legislation, the multi-functionality of soil may also be lost, since soil functions are addressed separately in different directives [77]. Many national governments insist that soil is a national issue, but they have passed almost no new national or regional legislation to protect the soil in recent years [78]. Moreover, there are national governments in the EU, which dispute the transboundary aspects of soil degradation [78]. Another argument against worries over sovereignty, is that the existing national soil protection laws of Member States would not be threatened by common EU legislation, as Member States may adopt laws that are more protective than EU legislation. Sharing best practice in soil protection at the European level would also be an asset, as a flexible and proportionate approach complements existing national action. A common European soil conservation policy would provide benefit to the EU by also addressing non-economical, societal challenges and in this way may better justify soil legislation. There are also other economic considerations which separate national legislations lack. Wide differences between national soil protection regimes, can in some cases impose on economic operators very different obligations, creating imbalance and a distortion of competition in the internal market. Acting at Community level would also greatly complement the quality controls performed at the national level to ensure food safety. 
Table 1. Legislative acts of selected EU Member States on main soil threats and their relationships to the proposed Soil Framework Directive of the EU.

\begin{tabular}{|c|c|c|c|c|c|c|}
\hline & \multicolumn{3}{|c|}{$\begin{array}{l}\text { Main Features of Legislative Acts (EU Member States) and } \\
\text { the Proposed Soil Framework Directive (SFD) of the EU by Different Types of Soil Threats }\end{array}$} & \multirow{3}{*}{$\begin{array}{l}\text { Force of the } \\
\text { Legal } \\
\text { Instuments * }\end{array}$} & \multirow{3}{*}{$\begin{array}{l}\text { LEVEL of } \\
\text { Similarity ** } \\
\text { between the SFD } \\
\text { and National } \\
\text { Legislations }\end{array}$} & \multirow{3}{*}{$\begin{array}{l}\text { Possible Means of } \\
\text { Harmonization } \\
\text { towards Consistent } \\
\text { Approaches between } \\
\text { MS Legislation and } \\
\text { the Proposed SFD }\end{array}$} \\
\hline & $\begin{array}{l}\text { Type I. } \\
\end{array}$ & $\begin{array}{l}\text { Type II. } \\
\end{array}$ & Type III. & & & \\
\hline & $\begin{array}{c}\text { Soil-Dependent Threats } \\
\text { (Erosion, Organic Matter Decline, } \\
\text { Salinisation, Compaction and Landslides) }\end{array}$ & Contamination & Sealing & & & \\
\hline $\begin{array}{l}\text { The proposed } \\
\text { Framework } \\
\text { Directive }\end{array}$ & $\begin{array}{l}\text { Identify the risk areas (reviewed every ten } \\
\text { years, Article 6) } \\
\text { For each risk area draw up a programme of } \\
\text { measures (in place max. eight years after } \\
\text { transposition date Article 8) }\end{array}$ & $\begin{array}{l}\text { Limit dangerous substances in the soil } \\
\text { (Article 9); } \\
\text { Identify contaminated sites and review } \\
\text { every five years (Article 10); } \\
\text { Status report at transaction (Article 12); } \\
\text { National Remediation Strategy shall be } \\
\text { published within seven years from } \\
\text { transposition date (Article 23, 14) }\end{array}$ & $\begin{array}{l}\text { Appropriate measures to limit } \\
\text { sealing or to mitigate its effects } \\
\text { (article 5) }\end{array}$ & & & \\
\hline UK & $\begin{array}{l}\text { CAP cross compliance, Environmental } \\
\text { Stewardship, the England Catchment Sensitive } \\
\text { Farming Delivery Initiative, and the new Code } \\
\text { of Good Agricultural Practice } \\
\text { These requirements are Good Agricultural and } \\
\text { Environmental Conditions (GAECs) and } \\
\text { Scheduled Monuments Statutory Management } \\
\text { Requirements (SMRs) } \\
\text { The Scottish Soil Framework, Environment } \\
\text { Strategy for Wales }\end{array}$ & $\begin{array}{l}\text { Environmental Protection Act } 1990 \text { (EPA): } \\
\text { identification, remediation. } \\
\text { Environmental Damage Regulations } 2015 \\
\text { (EDR): prevention and remediation in the } \\
\text { most serious cases. } \\
\text { DEFRA: Statutory Guidance for England on } \\
\text { dealing with contaminated land and } \\
\text { radioactive contaminated land. }\end{array}$ & $\begin{array}{l}\text { Planning system for considerations } \\
\text { of mitigating the impacts of soil } \\
\text { sealing, particularly in relation to } \\
\text { urban drainage and maintaining } \\
\text { green infrastructure. }\end{array}$ & $\begin{array}{l}\text { Type I. } \\
\text { [B] } \\
\text { Type II. } \\
\text { [B] } \\
\text { Type III. } \\
\text { [NB] }\end{array}$ & $\begin{array}{c}\text { Type I. } \\
\quad+ \\
\text { Type II. } \\
++ \\
\text { Type III. } \\
--\end{array}$ & $\begin{array}{l}\text { Type I. } \\
\text { technical } \\
\text { Type II. } \\
\text { technical } \\
\text { Type III. } \\
\text { legislative }\end{array}$ \\
\hline Germany & $\begin{array}{l}\text { Federal: UBA main environmental protection } \\
\text { agency and the Federal Ministry of } \\
\text { Environment carry out compiles, assesses, } \\
\text { and provide information on soil status, soil } \\
\text { conservation, and optimization of } \\
\text { measures.Sustainable Development Strategy to } \\
\text { clarify how Germany can achieve "land } \\
\text { degradation neutrality" domestically. } \\
\text { Federal Nature Conservation Act }\end{array}$ & $\begin{array}{l}\text { Official identification, remediation system } \\
\text { on both federal and local levels. } \\
\text { Federal Soil Protection Act, }\end{array}$ & $\begin{array}{l}\text { Federal Building Code, Federal } \\
\text { Spatial Planning Act The Federal } \\
\text { Building Code in urban planning. } \\
\text { Federal Regional Planning Act } \\
\text { (Raumordnungsgesetz) 30-ha goal }\end{array}$ & $\begin{array}{l}\text { Type I. } \\
\text { [B] } \\
\text { Type II. } \\
\text { [B] } \\
\text { Type III. } \\
\text { [B] }\end{array}$ & $\begin{array}{c}\text { Type I. } \\
++ \\
\text { Type II. } \\
++ \\
\text { Type III. } \\
++\end{array}$ & $\begin{array}{l}\text { Type I. } \\
\text { technical } \\
\text { Type II. } \\
\text { technical } \\
\text { Type III. } \\
\text { technical }\end{array}$ \\
\hline
\end{tabular}


Table 1. Cont.

\begin{tabular}{|c|c|c|c|c|c|c|}
\hline & \multicolumn{3}{|c|}{$\begin{array}{l}\text { Main Features of Legislative Acts (EU Member States) and } \\
\text { the Proposed Soil Framework Directive (SFD) of the EU by Different Types of Soil Threats }\end{array}$} & \multirow{3}{*}{$\begin{array}{l}\text { Force of the } \\
\text { Legal } \\
\text { Instuments * }\end{array}$} & \multirow{3}{*}{$\begin{array}{l}\text { LEVEL of } \\
\text { Similarity ** } \\
\text { between the SFD } \\
\text { and National } \\
\text { Legislations }\end{array}$} & \multirow{3}{*}{$\begin{array}{l}\text { Possible Means of } \\
\text { Harmonization } \\
\text { towards Consistent } \\
\text { Approaches between } \\
\text { MS Legislation and } \\
\text { the Proposed SFD }\end{array}$} \\
\hline & $\begin{array}{l}\text { Type I. } \\
\end{array}$ & $\begin{array}{l}\text { Type II. } \\
\end{array}$ & Type III. & & & \\
\hline & $\begin{array}{c}\text { Soil-Dependent Threats } \\
\text { (Erosion, Organic Matter Decline, } \\
\text { Salinisation, Compaction and Landslides) }\end{array}$ & Contamination & Sealing & & & \\
\hline France & $\begin{array}{l}\text { National information system:GIS Sol. } \\
\text { Ministry of Agriculture and of Environment, } \\
\text { Environment and Energy Agency (Ademe) } \\
\text { National Institute for Agricultural Research } \\
\text { (Inra) Research Institute for Development (IRD). }\end{array}$ & $\begin{array}{l}\text { ICPE, Environment Code a proactive } \\
\text { regulatory watch on soil problems and } \\
\text { administrative and criminal sanctions. }\end{array}$ & $\begin{array}{l}\text { National Strategy for Sustainable } \\
\text { Development, law Grenelle } \\
\text { Environment }\end{array}$ & $\begin{array}{l}\text { Type I. } \\
\text { [B] } \\
\text { Type II. } \\
\text { [B] } \\
\text { Type III. } \\
\text { [NB] }\end{array}$ & $\begin{array}{c}\text { Type I. } \\
+ \\
\text { Type II. } \\
++ \\
\text { Type III. } \\
- \\
\end{array}$ & $\begin{array}{l}\text { Type I. } \\
\text { legislative } \\
\text { Type II. } \\
\text { technical } \\
\text { Type III. } \\
\text { legislative }\end{array}$ \\
\hline Austria & $\begin{array}{l}\text { Soil Monitoring System and a Soil Information } \\
\text { System (BORIS) } \\
\text { Soil Protection Acts in } 5 \text { provinces. }\end{array}$ & $\begin{array}{l}\text { No integrated regulatory regime, but } \\
\text { applicable provisions are spread over } \\
\text { a considerable number of laws and } \\
\text { regulations (for example, the Trade Act, } \\
\text { the Federal Waste Management Act, } \\
\text { the Federal Environmental Liability Act, } \\
\text { the Forest Act, and the Water Act). } \\
\text { The Clean-up of Contaminated Sites Act } \\
\text { and the Directive on Funding Clean-Up of } \\
\text { Contaminated Land }\end{array}$ & $\begin{array}{l}\text { Austrian Strategy for Sustainable } \\
\text { Development, Report on } \\
\text { Monitoring Sustainable } \\
\text { Development. }\end{array}$ & $\begin{array}{l}\text { Type I. } \\
\text { [B] } \\
\text { Type II. } \\
\text { [B] } \\
\text { Type III. } \\
\text { [NB] }\end{array}$ & $\begin{array}{c}\text { Type I. } \\
+ \\
\text { Type II. } \\
+ \\
\text { Type III. } \\
-\end{array}$ & $\begin{array}{l}\text { Type I. } \\
\text { legislative } \\
\text { Type II. } \\
\text { legislative } \\
\text { Type III. } \\
\text { legislative }\end{array}$ \\
\hline NL & $\begin{array}{l}\text { Soil Protection Act (Wbb) Environmental } \\
\text { Protection Act (Wm) } \\
\text { Competent authority municipalities } \\
\text { Netherlands Soil Protection Guideline (NRB), } \\
\text { Directorate General for the Environment } \\
\text { (VROM/DGM), } \\
\text { Union of Water Boards Association of Provinces, } \\
\text { and Association of Netherlands Municipalities }\end{array}$ & $\begin{array}{l}\text { Soil Protection Act } \\
\text { Environmental Protection Act } \\
\text { Soil Quality Decree } \\
\text { Soil Remediation Circular } 2013 \\
\text { Cost Calculation Model (AOA) }\end{array}$ & $\begin{array}{l}\text { National Spatial Planning } \\
\text { Programmes by the Ministry for } \\
\text { Housing, Spatial Planning and the } \\
\text { Environment (Rijksoverheid) } \\
\text { The most recent development: } \\
\text { Nota Ruimte (NR) programme } \\
\text { Spatial Planning Act }\end{array}$ & $\begin{array}{l}\text { Type I. } \\
\text { [B] } \\
\text { Type II. } \\
\text { [B] } \\
\text { Type III. } \\
\text { [B] }\end{array}$ & $\begin{array}{c}\text { Type I. } \\
+ \\
\text { Type II. } \\
++ \\
\text { Type III. } \\
++\end{array}$ & $\begin{array}{l}\text { Type I. } \\
\text { technical } \\
\text { Type II. } \\
\text { technical } \\
\text { Type III. } \\
\text { legislative }\end{array}$ \\
\hline
\end{tabular}

* Force of the legal instruments: [B] Binding instruments also called 'hard law' confer legal obligations, which can be enforced by a body of law. [NB] Non-binding documents, also called 'soft law', cannot be enforced, but provide guidelines of conduct, reflect principles and proclaim standards. They are intended to influence the development of national laws and practices mostly in the form of declarations, recommendations and resolutions and can be implemented through programmes and action plans. ${ }^{* *}$ level of similarity: $(--)$ no legislation available; $(-)$ legislation exists, but with different conceptual approach and different implementation; $(+)$ legislation exist with similar conceptual approach but different implementation; $(++)$ legislation exist with similar conceptual approach and similar implementation. ${ }^{* * *}$ possible means of harmonization: technical (technical solution would be adequate: in cases when legislation exists with similar conceptual approach but there are minor practical differences in the implementation, e.g., temporal terms, terms of monitoring); legislative (legislative measures would be required). 


\section{Conclusions}

Most of the existing national environmental provisions recognize the problem of soil threats, and the importance of preserving soil functions. However, regulatory means of soil protection are mostly embedded into wider environmental legislation. Thus, soil protection, in many countries ends up as a by-product in measures often lacking the required authority to reinforce soil protection. Commonly, there is a lack of an overarching soil protection legislation and existing national policies are sometimes insufficient for preserving soil functions and combatting soil threats (halt erosion, soil sealing, etc.), as seen from the status of soil in the EU [79].

Nevertheless, we can state that in the five countries blocking the Directive soil protection, laws on soil-dependent degradation and contamination are often more restrictive than the proposed EU regulation. Therefore, the worries over sovereignty could not have reasonably arisen in this aspect. Soil sealing is an issue where the proposed Directive's measures, could have exceeded those of the Member States.

Liability implications were also included in the arguments opposing the proposed Directive, in cases when the liable party is not found, and the state would be responsible for remediation. In these subjects, technical solutions would be adequate to reach harmonised approaches for soil protection across the EU.

Results of our gap analysis suggest that-although legislation related to soil protection may be fragmented in some states-overall gaps in the contents of soil protection legislations are rather narrow among the EU member states. Thus, given that an agreement on the control of soil sealing can be reached, technical solutions are available to support the construction of a common political will to introduce a common soil protection legislation in the EU.

Author Contributions: The manuscript was written by P.S. and it was mentored by Z.T. The article subject was determined by G.T. who revised and improved the content throughout the drafting and publication process.

Funding: The publication is supported by the EFOP-3.6.3-VEKOP-16-2017-00008 project. The project is co-financed by the European Union and the European Social Fund. The research leading to these results has received funding from the European Union under Horizon-2020 Programme grant agreement No. 635750 (iSQAPER project, http: / / www.isqaperproject.eu/) and grant agreement No. 774234 (LANDSUPPORT project) and was also supported by the Hungarian National Research, Development and Innovation Office (NRDI) under grant KH124765.

Conflicts of Interest: The authors declare no conflict of interest.

\section{References}

1. Roser, M.; Ortiz-Ospina, E. World Population Growth. Available online: https://ourworldindata.org/world -population-growth (accessed on 18 December 2017).

2. Food and Agriculture Organization of the United Nations (FAO). Status of the World's Soil Resources. Available online: http:/ / www.fao.org/3/a-i5199e.pdf (accessed on 18 December 2017).

3. Agriculture and Fisheries Council. Three Square Kilometres of Soil Destroyed Every Day in Europe. Available online: https:/ / www.eu2017.ee/news/insights/three-square-kilometres-soil-destroyed-every-day-europe (accessed on 19 January 2018).

4. European Parliament and the Council. Decision No 1386/2013/EU on a General Union Environment Action Programme to 2020 'Living Well, within the Limits of our Planet'. Official Journal of Europe Union 2013, L 354/171. Available online: http:/ / ec.europa.eu/environment/action-programme/ (accessed on 10 January 2018).

5. Europian Commision. Environment, Soil. Available online: http://ec.europa.eu/environment/soil/index_ en.htm (accessed on 18 December 2017).

6. EUR-Lex. Better Regulation for Better Results-An EU Agenda. Available online: http:/ / eur-lex.europa.e u/legal-content/EN/TXT/?uri=CELEX:52017SC00460 (accessed on 7 February 2018).

7. Starlinger, T.; Trenkwalder, A. Environment Austria. Available online: https://gettingthedealthrough.com/ area/13/jurisdiction/25/environment-austria/ (accessed on 7 February 2018). 
8. ENVASSO: Environmental Assessment of Soil for Monitoring. Available online: https:/ / esdac.jrc.ec.europa. eu/projects / envasso (accessed on 8 February 2018).

9. Euroactiv. EU Soil Protection Law Blocked by UK, France and Germany. Available online: http:/ / www.euro activ.com/section/climate-environment/news/eu-soil-protection-law-blocked-by-ukfrance-and-germany (accessed on 18 December 2017).

10. Comission of The European Communities. Report from the Commission to the European Parliament, the Council, the European Economic and Social Committee and the Committee of the Regions-The Implementation of the Soil Thematic Strategy and Ongoing Activities. Available online: http://eur-le x.europa.eu/legal-content/EN/TXT/?uri=CELEX:52012DC0046 (accessed on 7 February 2018).

11. Glaesner, N.; Helming, K.; de Vries, W. Do current European policies prevent soil threats and support soil functions? Sustainability 2014, 6, 9538-9563. [CrossRef]

12. Schulte, R.P.O.; Creamer, R.E.; Donnellan, T.; Farrelly, N.; Fealy, R.; O’Donoghue, C.; O'hUallachain, D. Functional land management: A framework for managing soil-based ecosystem services for the sustainable intensification of agriculture. Environ. Sci. Policy 2014, 38, 45-58. [CrossRef]

13. Vrebos, D.; Bampa, F.; Creamer, R.E.; Gardi, C.; Ghaley, B.B.; Jones, A.; Rutgers, M.; Sandén, T.; Staes, J.; Meire, P. The Impact of Policy Instruments on Soil Multifunctionality in the European Union. Sustainability 2017, 9, 407. [CrossRef]

14. Commission of the European Communities. Proposal for a Directive of the European Parliament and of the Council Establishing a Framework for the Protection of Soil and Amending Directive 2004/35/EC, (Soil Framework Directive), Article 6. Available online: http:/ / eur-lex.europa.eu/legal-content/EN/TXT/?uri= celex:52006PC0232 (accessed on 23 May 2018).

15. Soil Framework Directive, Article 8. Available online: https://eur-lex.europa.eu/legal-content/EN/TXT/? uri=CELEX:52006PC0232 (accessed on 23 May 2018).

16. Soil Framework Directive, Article 9. Available online: https:/ / eur-lex.europa.eu/legal-content/EN/TXT/? uri=CELEX:52006PC0232 (accessed on 23 May 2018).

17. Soil Framework Directive, Explanatory Memorandum Context of the Proposal, (24). Available online: https:/ / eur-lex.europa.eu/legal-content/EN/TXT/?uri=CELEX:52006PC0232 (accessed on 23 May 2018).

18. Soil Framework Directive, Article 10. Available online: https://eur-lex.europa.eu/legal-content/EN/TXT/? uri=CELEX:52006PC0232 (accessed on 23 May 2018).

19. Soil Framework Directive, Article 12. Available online: https://eur-lex.europa.eu/legal-content/EN/TXT/? uri=CELEX:52006PC0232 (accessed on 23 May 2018).

20. Soil Framework Directive, Article 5. Available online: https:/ / eur-lex.europa.eu/legal-content/EN/TXT/? uri=CELEX:52006PC0232 (accessed on 23 May 2018).

21. Brady, J.; Ebbage, A.; Lunn, R. Environmental Management in Organizations: The IEMA Handbook; Routledge: London, UK, 2013; p. 376.

22. The Scottish Government. The Scottish Soil Framework. Available online: http://www.gov.scot/Publicati ons /2009/05/20145602/0 (accessed on 22 May 2018).

23. Welsh Assembly Government: Environment Strategy for Wales. Available online: http://gov.wales/topics / environmentcountryside/epq/Envstratforwales/ / ?lang=en (accessed on 22 May 2018).

24. Guide to Cross Compliance in England. For Example: GAEC 4-Providing Minimum Soil Cover, GAEC 5-Minimising Soil Erosion, GAEC 6-Maintaining the Level of Organic Matter in Soil and SMR 1: Nitrate Vulnerable Zones (NVZs). Available online: https:/ / www.gov.uk/guidance/guide-to-cross-compliance-in -england-2016/gaec-5-minimising-soil-erosion (accessed on 23 May 2018).

25. Defra. Cross Compliance Guidance for Soil Management 2010 Edition. Available online: http:/ / adlib.everys ite.co.uk/resources/000/262/251/PB13315.pdf (accessed on 20 February 2018).

26. Ashurst. Limitation and Exclusion of Liability. Available online: https://www.ashurst.com/en/news-andinsights /legal-updates / quickguide-limitation-and-exclusion-of-liability / (accessed on 28 January 2018).

27. Coxall, M.; Hardacre, E. Environmental Law and Practice in the UK (England and Wales). Available online: https: / / uk.practicallaw.thomsonreuters.com / 65031654?transitionType=DefaultcontextData=(sc.D efault)firstPage=truebhcp=1\#co_anchor_a427993 (accessed on 28 January 2018).

28. Department for Environment, Food and Rural Affairs: Safeguarding our Soils a Strategy for England. Available online: https://www.gov.uk/government/uploads/system/uploads/attachment_data/file/69 261/pb13297-soil-strategy-090910.pdf (accessed on 22 March 2018). 
29. National Soil Resources Institute; Wood, G.; Braganza, S.; Brewer, T.; Kampouraki, M.; Harris, J.; Hannam, J.; Burton, R.; Deane, G. Monitoring Urban Sealing from Space-Technical Report of GIFTSS Project BNSC/ITT/54, Defra Code SP0541. Cranfield University, School of Applied Sciences, Bedfordshire, MK43 0AL 2 Infoterra Ltd., Farnborough, Hampshire, GU14 0NL August. 2006. Available online: Randd.defra.gov.uk/Document.aspx?Document=SP0541_5218_FRP.pdf (accessed on 22 March 2018).

30. Act on Protection against Harmful Changes to Soil and on Rehabilitation of Contaminated Sites. Federal Law Gazette I p. 502, (BBodSchG), Article 3. Available online: https:/ / germanlawarchive.iuscomp.org/?p=322 (accessed on 20 March 2018).

31. BBodSchG, Article 17. Available online: https://www.gesetze-im-internet.de/bbodschg/_1.html (accessed on 18 February 2018).

32. BBodSchG, Section 1 of the Act. Available online: https://www.gesetze-im-internet.de/bbodschg/__1.html (accessed on 18 February 2018).

33. Umweltbundesamt: Soil Protection. Available online: https://www.umweltbundesamt.de/en/topics/soilagriculture/soil-protection (accessed on 18 February 2018).

34. Umweltbundesamt: Site Contamination. Available online: https://www.umweltbundesamt.de/en/topics / soil-agriculture/site-contamination (accessed on 18 February 2018).

35. Facts on German Legislation and Regulations on Brownfields and Contaminated Sites. Available online: http:/ / www.katumwelt.de/Neue\%20Seiten/brownfields-germany.htm (accessed on 18 February 2018).

36. EUGRIS: Policy and Regulation: Germany Contaminated land. Available online: http:/ /www.eugris.info/ Policy.asp $\mathrm{e}=276 \mathrm{Ca}=1 \mathrm{Cy}=10 \mathrm{~T}=$ Contaminated\%20land (accessed on 18 February 2018).

37. Behnisch, M.; Poglitsch, H.; Krüger, T. Soil Sealing and the Complex Bundle of Influential Factors: Germany as a Case Study. Available online: File:/ / F: /Let\%C3\%B61t\%C3\%A9sek/ijgi-05-00132-v2.pdf (accessed on 18 January 2018).

38. Department of Economic and Social Affairs: Executive Summary of the Report of the German Government to the High-Level Political Forum in July 2016. Available online: https:/ / sustainabledevelopment.un.org/ memberstates/germany (accessed on 10 February 2018).

39. Federal Government: German Sustainable Development Strategy Summary. Available online: http://www. minsk.diplo.de/contentblob/5063918/Daten/7599968/Deutsche_Nachhaltigkeitsstrategie_ru.pdf (accessed on 18 February 2018).

40. Klauer, B.; Manstetten, R.; Petersen, T.; Schiller, J. Sustainability and the Art of Long-Term Thinking; Taylor Francis: Oxford, UK, 2016; p. 27.

41. Wunder, S. Implementation of "Land Degradation Neutrality" in Germany. Available online: https://www. ecologic.eu/13970 (accessed on 18 February 2018).

42. Gis Sol. Partageons la Connaissance des Sols. Available online: http://www.gissol.fr/ (accessed on 15 March 2018).

43. Environment Code Articles L 2212-2 and L. 2212-4. Available online: http:/ / www.wipo.int/wipolex/en/de tails.jsp?id=6040 (accessed on 15 March 2018).

44. Brenot, V. Environmental Law and Practice in France. Available online: https:/ / content.next.westlaw.com /Document/I203078fd1cb611e38578f7ccc38dcbee/View / FullText.html?contextData=(sc.Default)transitio nType $=$ DefaultfirstPage $=$ truebhcp $=1$ (accessed on 18 February 2018).

45. Ginzky, H.; Dooley, E.; Heuser, I.L.; Kasimbazi, E.; Markus, T.; Qin, T. International Yearbook of Soil Law and Policy 2017; Springer: Berlin, Germany, 2017; p. 283; ISBN 9783319688855.

46. ICPE: Installations Classées pour la Protection de L'Eenvironnement, “Classified Facilities for Protection of the Environment" Legislation. Available online: https://www.rskgroup.fr/en/item/57-icpe-permitting.h tml (accessed on 14 February 2018).

47. Environment Code. (L. 556-1 to L. 556-3 and R. 556-1). Articles L. 125-6 and L. 125-7. Available online: https: / uk.practicallaw.thomsonreuters.com/w0105542?transitionType=DefaultcontextData=(sc .Default)firstPage=truecomp=plukbhcp=1 (accessed on 23 January 2018).

48. Environment Code, Articles L.125-6. Available online: https://www.legifrance.gouv.fr/content/download/ 1963/13739/.../3/.../Code_40.pdf (accessed on 23 January 2018).

49. Environment Code, Articles L. 556-3 I. Available online: https:/ /www.legifrance.gouv.fr/content/downloa d/1963/13739/.../3/.../Code_40.pdf (accessed on 23 January 2018). 
50. Environment Code Article L. 556-3 II. Available online: https:/ / www.legifrance.gouv.fr/content/downloa d/1963/13739/.../3/.../Code_40.pdf (accessed on 23 January 2018).

51. Brenot, V. Environmental Law and Practice in France. Available online: https:/ /uk.practicallaw.thomsonreu ters.com/7-503-4572?_lrTS=20170927122335224transitionType=DefaultcontextData=(sc. Default)firstPage =truebhcp=1 (accessed on 14 February 2018).

52. The European Commission. DG Environment: Overview of Best Practices for Limiting Soil Sealing or Mitigating its Effects in EU-27; EU Publication: Luxembourg, 2011; p. 79; ISBN 978-92-79-20669-6. [CrossRef]

53. Huber, S. National Activities on Soil in Austria. Available online: http:/ / eusoils.jrc.ec.europa.eu/Library/D ata/EIONET/Presentations / Austria.pdf (accessed on 14 February 2018).

54. Blum, W.E.H.; Englisch, M.; Nelhiebl, P.; Schneider, W.; Schwarz, S.; Wagner, J. Soil Survey and Soil Data in Austria. Available online: http://eusoils.jrc.ec.europa.eu/ESDB_Archive/eusoils_docs/esb_rr/n06_soil resources_of_europe/PDF/AUST05.pdf (accessed on 14 February 2018).

55. Umweltbundesamt/Federal Environment Agency. 6th Report on the State of the Environment in Austria-6 Soil. Available online: http:/ / www.umweltbundesamt.at/fileadmin/site/umweltkontrolle/2001/E-06_ boden.pdf (accessed on 14 February 2018).

56. National Implementation of Agenda 21: A Summary. Available online: http://www.un.org/esa/agenda21/ natlinfo/countr/austria/land.pdf (accessed on 23 January 2018).

57. FAO (Food and Agriculture Organization). FAOLEX Database. Available online: http://www.fao.org/faol ex/results / details/en/?details=LEX-FAOC081702 (accessed on 23 January 2018).

58. Schmelz, C.; Rajal, B. Environment 2013-Austria. Available online: http:/ /www.mondaq.com/Austria/x /206958/Waste+Management/Environment+2013+Austria (accessed on 23 January 2018).

59. Prokop, G.; Jobstmann, H.; Schönbauer, A. Environment Agency Austria: Report on Best Practices for Limiting Soil Sealing and Mitigating its Effects. Available online: http:/ / ec.europa.eu/environment/archi ves/soil/pdf/sealing/Soil\%20sealing\%20-\%20Final\%20Report.pdf (accessed on 22 March 2018).

60. Rijkswaterstaat Environment: Dutch “Institutional Structure". Available online: File:/ / C: /Users/User/Deskto p/k\%C3\%A9s\%C5\%91bb\%20t\%C3\%B6r\%C3\%B6lhrt\%C5\%91/institutional_structure_24_309965\%20(1).pdf (accessed on 23 January 2018).

61. Netherlands Soil Protection Guideline for Industrial Activities. Available online: https://rwsenvironment.e $\mathrm{u}$ /subjects/soil/legislation-and/soil-protection/ (accessed on 23 January 2018).

62. Dutch "Institutional Structure". Available online: File:/ / /F:/Let\%C3\%B61t\%C3\%A9sek/institutional_struct ure_24_309965\%20(1).pdf (accessed on 21 February 2018).

63. Ministry of Infrastructure and the Environment: Legislation and Instruments. Available online: https: / / rwsenvironment.eu/subjects/soil/legislation-and/ (accessed on 21 February 2018).

64. Soil Quality Decree. Available online: https://rwsenvironment.eu/subjects/soil/legislation-and/soil-quali ty-decree/ (accessed on 21 February 2018).

65. Ministry of Infrastructure and Water Management. Cost Calculation Model Area Oriented Approach. Available online: https:/ / rwsenvironment.eu/subjects/soil/legislation-and/cost-calculation/ (accessed on 21 February 2018).

66. SIKB. Available online: www.sikb.nl (accessed on 21 February 2018).

67. Buitelaar, E.; Sorel, N. Between the rule of law and the quest for control: Legal certainty in the Dutch planning system. Land Use Policy 2010, 27, 983-989. [CrossRef]

68. Paleari, S. Is the European Union Protecting Soil? A Critical Analysis of Community Environmental Policy and Law. Land Use Policy 2017, 64, 163-173. [CrossRef]

69. Bowyer, C.; Albrecht, S.; Keenleyside, C.; Kemper, M.; Nanni, S.; Naumann, S.; Mottershead, D.; Landgrebe, R.; Andersen, E.; Banfi, P.; et al. Updated Inventory and Assessment of Soil Protection Policy Instruments in EU Member States. Final Report to DG Environment. 2016. Berlin: Ecologic Institute. Available online: http:/ / ec.europa.eu/environment/soil/pdf/Soil_inventory_report.pdf (accessed on 7 February 2018).

70. Reimer, M.; Getimis, P.; Blotevogel, H. Spatial Planning Systems and Practices in Europe: A Comparative Perspective on Continuity and Changes; Routledge: London, UK, 2014; p. 336; ISBN 978-0-415-72723-5.

71. Tosics, I.; Szemző, H.; Illés, D.; Gertheis, A. PLUREL. National Spatial Planning Policies and Governance Typology; Deliverable Report 2.2.1. Available online: http:/ / www.plurel.org/images/D221.pdf (accessed on 17 September 2017). 
72. Oliver, L.; Ferber, U.; Grimski, D.; Nathanail, P. The Scale and Nature of European Brownfields. CABERNET Working Paper 2005. Available online: https://www.researchgate.net/profile/Uwe_Ferber/publication/2 28789048_The_Scale_and_Nature_of_European_Brownfield/links/5469e8300cf20dedafd20077/The-Scaleand-Nature-of-European-Brownfield.pdf (accessed on 17 September 2017).

73. Oliveira, E.; Hersperger, A.M. Governance Arrangements, Funding Mechanisms and Power Configurations in Current Practices of Strategic Spatial Plan Implementation. Land Use Policy 2018. Available online: https:/ / doi.org/10.1016/j.landusepol (accessed on 22 May 2018).

74. The European Environment Agency. Soil degradation. Available online: https://www.eea.europa.eu/publ ications /92-9157-202-0/page306.html (accessed on 22 March 2018).

75. Johns, N. Why Was the Soil Framework Directive with Drawn? Available online: https://blogs.lexisnexis.co. uk/purposebuilt/why-was-the-soil-framework-directive-withdrawn/ (accessed on 22 March 2018).

76. FAO_Global Soil Partnership. The Voluntary Guidelines for Sustainable Soil Management for the Achievement of a Zero Hunger World. Available online: http:/ /www.fao.org/global-soil-partnership/reso urces/events/detail/en/c/1042165// (accessed on 3 June 2018).

77. Berge, H.F.M.; Schröder, J.J.; Olesen, J.E.; Giraldez Cervera, J.-V. Research for AGRI Committee-Preserving Agricultural Soils in the EU. Available online: http:/ / www.europarl.europa.eu/RegData/etudes/STUD/2 017/601973/IPOL_STU(2017)601973_EN.pdf (accessed on 26 March 2018).

78. Keating, D. Europe's Environmental Laws Overlook Vital Soil. Available online: http://www.dw.com/en/ global-ideas-soil-erosion-agriculture-europe/a-18807131 (accessed on 26 March 2018).

79. Jones, A.; Panagos, P.; Barcelo, S.; Bouraoui, F.; Bosco, C.; Dewitte, O.; Gardi, C.; Ehrhard, M.; Hervás, J.; Hiederer, R.; et al. The State of Soil in Europe; JRC Reference Reports; Publication Office of the European Union: Luxembourg, 2012.

(C) 2018 by the authors. Licensee MDPI, Basel, Switzerland. This article is an open access article distributed under the terms and conditions of the Creative Commons Attribution (CC BY) license (http:/ / creativecommons.org/licenses/by/4.0/). 